Journal of Telenursing (JOTING)

Volume 3, Nomor 1, Juni 2021

e-ISSN: 2684-8988

p-ISSN: 2684-8996

DOI: https://doi.org/10.31539/joting.v3i1.2112

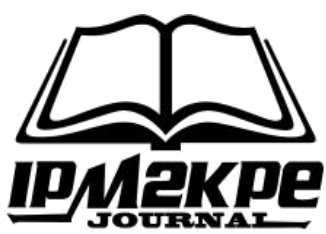

\title{
TINGKAT PENGETAHUAN WUS DENGAN KEIKUTSERTAAN TES IVA SEBAGAI UPAYA DETEKSI DINI KANKER SERVIKS
}

\author{
Putu Indah Sintya Dewi ${ }^{1}$, Luh Ayu Purnami ${ }^{2}$, Putu Agus Ariana ${ }^{3}$, \\ Ni Komang Ayu Arcawati ${ }^{4}$ \\ Sekolah Tinggi Ilmu Kesehatan Buleleng ${ }^{1,2,3,4}$ \\ indahsintya88@gmail.com ${ }^{1}$
}

\begin{abstract}
ABSTRAK
Penelitian ini bertujuan untuk mengetahui dan menganalisis hubungan tingkat pengetahuan terhadap keikutsertaan Wanita Usia Subur (WUS) dalam pemeriksaan Inspeksi Visual Asam Asetat (IVA). Penelitian ini menggunakan metode survey analitik dengan pendekatan cross-sectional. Hasil analisis menggunakan uji Chi-Square menunjukkan bahwa nilai $\mathrm{p}$ adalah sebesar $0,001(\mathrm{p}<\mathrm{a} 0,005)$. Simpulan, ada hubungan antara tingkat pengetahuan dengan keikutsertaan WUS dalam pemeriksaan inspeksi visual asam asetat di wilayah kerja UPTD Puskesmas Blahbatuh II.
\end{abstract}

Kata Kunci: Inspeksi Visual Asam Asetat, Keikutsertaan, Pengetahuan

\section{ABSTRACT}

This study aims to determine and analyze the relationship between the level of knowledge and the participation of fertile aged women (WUS) in the visual inspection of acetic acid (IVA). This study used an analytic survey method with a cross-sectional approach. The analysis results using the Chi-Square test showed that the p-value was $0.001(p<a$ 0.005). In conclusion, there is a relationship between the level of knowledge and the participation of WUS in the visual inspection of acetic acid in the working area of the UPTD Puskesmas Blahbatuh II.

Keywords: Acetic Acid Visual Inspection, Participation, Knowledge

\section{PENDAHULUAN}

Kementerian Kesehatan RI menargetkan program cakupan deteksi dini kanker serviks sebesar $50 \%$ pada perempuan berusia 30-50 tahun yang dicapai pada tahun 2019. Sampai tahun 2014, cakupan deteksi dini kanker serviks yang telah dilakukan masih rendah yaitu sebesar 2,45\% dengan hasil Inspeksi Visual Asam Asetat (IVA) positif sebanyak 4,94\% dan suspek kanker serviks sebanyak 1.056 orang. Riskesdas 2018 menyebutkan prevalensi kanker di Provinsi Bali sebanyak 2,3 per mil. Kejadian ini meningkat dibandingkan hasil Riskesdas tahun 2013 sebanyak 2,0 per mil (Dinas Kesehatan Provinsi Bali, 2019).

Penelitian terkait kanker serviks terutama yang barkaitan dengan upaya deteksi dini pada kejadian tersebut sudah pernah dilakukan sebelumnya. Pemeriksaan dengan metode IVA merupakan satu diantara berbagai metode deteksi yang dapat dilakukan. Ada berbagai faktor yang mempengaruhi pasangan usia subur untuk melakukan tes ini. Menurut Rahmi \& Sinta (2020) partisipasi pasangan usia subur dalam melakukan tes 
IVA dipengaruhi oleh tingkat pendidikan. Penelitian ini merekomendasikan kepada petugas untuk mengembangkan strategi yang menarik agar dapat meningkatkan ketertarikan masyarakat untuk berpartisipasi dalam pemeriksaan IVA.

Penelitian lainnya yang berkaitan dengan pemeriksaan IVA adalah penelitian yang dilakukan untuk mengidentifikasi keikutsertaan pemeriksaan IVA melalui tinjauan karakteristik responden. Hasil penelitian tersebut menunjukkan bahwa terdapat hubungan antara umur, pendidikan dan pekerjaan dengan keikutsertaaan ibu dalam melakukan pemeriksaan IVA. Penelitian ini juga menyimpulkan bahwa faktor-faktor ini mempengaruhi pelaksanaan Tes IVA sebesar 41\% (Winarni \& Kanti, 2020).

Selain itu, menurut Adyani \& Realita (2020) terdapat beberapa faktor yang signifikan mempengaruhi keikutsertaan wanita usia subur dalam pemeriksaan IVA, yaitu akses informasi, dukungan keluarga, dukungan petugas dan dukungan petugas kesehatan. Berdasarkan penelitian tersebut, ditemukan bahwa dukungan keluarga menjadi faktor yang paling mempengaruhi dengan signifikan. Penelitian ini dilakukan pada 236 wanita usia subur yang telah menikah lebih dari 5 tahun. Namun, menurut Lestari et al., (2020) lebih dari 90\% wanita usia subur tidak melakukan pemeriksaan IVA. Penelitian yang dilakukan juga menemukan bahwa tidak terdapat hubungan antara pengetahuan, motivasi dan dukungan suami dengan perilaku pemeriksaan IVA.

Kesenjangan yang terjadi pada penelitian yang dilakukan sebelumnya merupakan fenomena yang menarik untuk dianalisis lebih jauh. Oleh karena itu, peneliti tertarik untuk melakukan kajian guna menjawab kesenjangan yang terjadi tentang pengetahuan dengan keikutsertaan wanita usia subur dalam pemeriksaan IVA melalui pendekatan studi kasus.

\section{METODE PENELITIAN}

Metode penelitian ini adalah kualitatif. Data dalam penelitian dikumpulkan melalui metode survei dengan menggunakan kuesioner. Penelitian dilakukan secara cross-sectional dengan menggunakan instrument kuesioner pengetahuan yang telah dilakukan uji validitas dan realibilitas dengan p-value > 0,6. Jumlah sampel dari penelitian sebanyak 57 WUS yang dihitung menggunakan rumus besaran sampel. Penelitian dilakukan selama 3 bulan dari September 2020 sampai dengan Desember 2020 bertempat di UPTD Puskesmas Blahbatuh II Gianyar.

\section{HASIL PENELITIAN}

Tabel. 1

Distribusi Frekuensi Karakteristik Wanita Usia Subur

\begin{tabular}{cccc}
\hline \multirow{2}{*}{ No } & Karakteristik & Frekuensi (N) & Persentase (\%) \\
\cline { 2 - 4 } & Usia & 16 & 30,2 \\
1 & 30-35 Tahun & 17 & 32,1 \\
2 & 36-40 Tahun & 12 & 22,6 \\
3 & $41-45$ Tahun & 8 & 15,1 \\
4 & 46-49 Tahun & 53 & 100 \\
\hline \multicolumn{5}{c}{ Jumlah } & 10 & 18,9 \\
\hline 1 & Pendidikan & 5 & 9,4 \\
\hline 2 & SD & 28 & 52,8 \\
4 & SMP & 10 & 18,9 \\
\hline \multicolumn{5}{c}{ SMA/SMK/SMEA } & 53 & 100
\end{tabular}




\begin{tabular}{lccc}
\hline & Pekerjaan & Frekuensi (N) & Persentase (\%) \\
\hline 1 & Karyawan Swasta & 23 & 43,4 \\
2 & Wiraswasta & 11 & 20,8 \\
3 & Buruh & 5 & 9,4 \\
4 & Ibu Rumah Tangga & 12 & 22,6 \\
5 & PNS/Kontrak & 2 & 3,8 \\
\hline & Jumlah & 53 & 100 \\
\hline
\end{tabular}

Hasil interpretasi tabel 1 memperlihatkan bahwa sebagian besar responden berumur 36-40 tahun yakni sebanyak 17 orang (32,1\%). Diketahui bahwa sebagian besar pendidikan responden adalah SMA/SMK/SMEA yakni sebanyak 28 orang $(52,8 \%)$ dan sebagian besar pekerjaan responden yakni karyawan swasta sebanyak 23 orang $(43,4 \%)$.

Tabel. 2

Distribusi Frekuensi Tingkat Pengetahuan Inspeksi Visual Asam Asetat

\begin{tabular}{cccc}
\hline No & Tingkat Pengetahuan & Frekuensi (n) & Persentase (\%) \\
\hline 1 & Kurang & 9 & 17,0 \\
2 & Cukup & 17 & 32,1 \\
3 & Baik & 27 & 50,9 \\
\hline & Jumlah & 53 & 100 \\
\hline
\end{tabular}

Berdasarkan interpretasi tabel 2, data menunjukkan bahwa sebagian besar tingkat pengetahuan berada dalam kategori baik sebanyak 27 orang $(50,9 \%)$.

Tabel. 3

Frekuensi Keikutsertaan WUS Dalam Pemeriksaan Inspeksi Visual Asam Setat

\begin{tabular}{cccc}
\hline No & $\begin{array}{c}\text { Keikutsertaan WUS dalam } \\
\text { Pemeriksaan IVA }\end{array}$ & Frekuensi (n) & Persentase (\%) \\
\hline 1 & Tidak & 23 & 43,4 \\
2 & Ya & 30 & 56,6 \\
\hline & Jumlah & 53 & 100 \\
\hline
\end{tabular}

Berdasarkan interpretasi tabel 3 diatas diperoleh hasil bahwa sebagian besar WUS pernah melakukan IVA sebanyak 30 orang $(56,6 \%)$.

Tabel. 4

Analisis Hubungan Tingkat Pengetahuan Terhadap Keikutsertaan WUS

Dalam Pemeriksaan Inspeksi Visual Asam Asetat

\begin{tabular}{|c|c|c|c|c|c|c|c|}
\hline \multirow{3}{*}{$\begin{array}{c}\text { Tingkat } \\
\text { Pengetahuan }\end{array}$} & \multicolumn{4}{|c|}{ Keikutsertaan } & \multirow{2}{*}{\multicolumn{2}{|c|}{ Jumlah }} & \multirow{3}{*}{$p$} \\
\hline & \multicolumn{2}{|c|}{ Tidak } & \multicolumn{2}{|c|}{$\mathrm{Ya}$} & & & \\
\hline & $\mathrm{F}$ & $\%$ & $\mathrm{~F}$ & $\%$ & $f$ & $\%$ & \\
\hline Kurang & 9 & 17,0 & & & 9 & 17,0 & \\
\hline Cukup & 4 & 7,5 & 13 & 24,5 & 17 & 32,1 & 0,001 \\
\hline Baik & 10 & 18,9 & 17 & 32,1 & 27 & 50,9 & \\
\hline Jumlah & 23 & 43,4 & 30 & 56,6 & 53 & 100 & \\
\hline
\end{tabular}

Berdasarkan interpretasi tabel 5, hasil analisis bivariat menggunakan uji ChiSquare menunjukkan bahwa nilai $\mathrm{p}=0,001$, sehingga $\mathrm{p}<\alpha(0,05)$. Hal ini berarti bahwa 
ada hubungan tingkat pengetahuan terhadap keikutsertaan WUS dalam pemeriksaan inspeksi visual asam asetat.

\section{PEMBAHASAN}

\section{Karakteristik Responden di Wilayah Kerja UPTD Puskesmas Blahbatuh II}

Berdasarkan hasil penelitian karakteristik umur didapatkan responden umur 30-35 tahun berjumlah 16 orang $(30,2 \%)$, umur 36-40 tahun berjumlah 17 orang $(32,1 \%)$, umur 41-45 tahun berjumlah 12 orang (22,6\%), umur 46-49 tahun berjumlah 8 orang $(15,1 \%)$. Karena sampel diambil dengan teknik simple random sampling, maka setiap WUS yang berada pada batasan usia 30-49 tahun dan masuk kriteria inkusi dapat dijadikan responden. Berdasarkan hasil penelitian, diketahui bahwa tidak terdapat hubungan yang signifikan antara umur dengan keikutsertaan WUS dalam melakukan pemeriksaan IVA di UPTD Puskesmas Blahbatuh II.

Hasil penelitian ini sejalan dengan penelitian yang dilakukan oleh (Winarni \& Kanti, 2020). Hasil penelitiannya tentang tinjauan karakteristik responden yang mengikuti tes IVA menunjukkan bahwa terdapat hubungan signifikan antara umur ibu dengan keikutsertaan pemeriksaan IVA. Dalam penelitian yang sudah dilakukan juga menunjukkan bahwa wanita yang berusia di atas 39 tahun memiliki kecenderungan sebesar 3.12 kali lebih besar untuk mengikuti tes IVA bila dibandingkan dengan yang berusia dibawah 39 tahun.

Berdasarakan pendidikan didapatkan distribusi frekuensi responden pendidikan SD berjumlah 10 orang $(18,9 \%)$, pendidikan SMP berjumlah 5 orang $(9,4 \%)$, SMA/SMK/SMEA berjumlah 28 orang $(52,8 \%)$, pendidikan perguruan tinggi berjumlah 10 orang $(18,9 \%)$. Hal ini menunjukan bahwa pada umumnya wanita pasangan usia subur di wilayah UPTD Puskesmas Blahbatuh II memiliki tingkat pendidikan yang cukup baik. Pendidikan memiliki hubungan dengan tingkat pengetahuan seseorang. Pendidikan yang baik akan kesehatan dapat meningkatkan pemahaman masyarakat untuk melakukan pemeriksaan IVA. Semakin tinggi pendidikan seseorang maka akan meningkatkan pengetahuan dibandingkan dengan mereka yang memiliki pendidikan rendah.

Hal ini sesuai dengan penelitian yang dilakukan oleh (Nuryawati, 2020). Penelitian yang dilakukan adalah penelitian kuantitatif dengan pendekatan crosssectional. Hasil penelitiannya menunjukkan bahwa proporsi wanita usia subur dalam melakukan pemeriksaan IVA yang memiliki pengetahuan kurang lebih kecil daripada yang memiliki pengetahuan yang baik tentang kanker serviks. Penelitian ini menyatakan bahwa terdapat hubungan antara pengetahuan tentang kanker serviks dengan pemeriksaan tes IVA. Berdasarkan OR pada penelitian yang dilakukan, pengetahuan kurang tentang Kanker serviks berpeluang 3, 29 kali lebih besar tidak memeriksaan IVA bila dibandingkan dengan yang memiliki pengetahuan Baik. Menurut asumsi peneliti, pendidikan yang lebih rendah akan lebih sulit memahami pesan atau informasi yang disampaikan. Pengetahuan diubungkan dengan pendidikan tinggi. Akan tetapi seseorang dengan pendidikan rendah bukan berarti berpengetahuan rendah.

Berdasarkan pekerjaan didapatkan distribusi frekuensi responden yaitu karyawan swasta berjumlah 23 orang $(43,3 \%)$, wiraswasta berjumlah 11 orang $(20,8 \%)$, buruh berjumlah 5 orang $(9,4 \%)$, IRT (ibu rumah tangga) berjumlah 12 orang $(22,6 \%)$, PNS/kontrak berjumlah 2 orang (3,8\%), sehingga dapat disimpulkan bahwa sebagian besar responden bekerja sebagai karyawan swasta. Wanita produktif memiliki interaksi yang lebih banyak dengan orang lain. Hal ini juga mempengaruhi jumlah informasi 
yang akan diperoleh. Faktor pekerjaan merupakan faktor yang signifikan dalam mempengaruhi keikutsertaan dalam pemeriksaan IVA. Hal ini sejalan dengan hasil temuan Winarni \& Kanti (2020) bahwa terdapat hubungan antara umur, pendidikan dan pekerjaan dengan keikutsertaaan ibu dalam melakukan pemeriksaan IVA.

\section{Tingkat Pengetahuan WUS tentang Pemeriksaan Inspeksi Visual Asam Asetat}

Hasil penelitian berdasarkan pengetahuan WUS didapatkan ibu yang memiliki pengetahuan kurang sebanyak 9 orang $(17,0 \%)$, ibu yang memilki pengetahuan cukup sebanyak 17 orang $(31,1 \%)$ dan ibu yang memiliki pengetahuan baik sebanyak 27 orang (50,9\%), sehingga dapat diambil kesimpulan pada penelitian ini bahwa pengetahuan responden tertinggi ada pada kategori baik.

Pengetahuan merupakan faktor yang penting namun tidak memadai dalam perubahan perilaku kesehatan. Responden yang memiliki pengetahuan yang tinggi mengenai pemeriksaan IVA akan cenderung memiliki kesadaran yang besar untuk meningkatkan status kesehatannya sehingga lebih besar kemungkinan melakukan pemeriksaan IVA. Pengetahuan yang tinggi belum tentu membuat seseorang mau secara sadar melakukan pemeriksaan IVA. Hal ini disebabkan oleh berbagai hal, diantaranya yaitu sosial budaya masyarakat yang menganggap pemeriksaan genetalia masih dianggap tabu, malu dan takut akan hasil yang diperoleh nantinya. Hal ini dapat digambarkan pada hasil penelitian sebelumnya yang dilakukan oleh Lestari et al., (2020) yang menemukan bahwa lebih dari $90 \%$ ibu tidak melakukan pemeriksaan IVA. Penelitian yang dilakukan juga menemukan bahwa tidak terdapat hubungan antara pengetahuan, motivasi dan dukungan suami dengan perilaku pemeriksaan IVA.

Responden yang memiliki pengetahuan yang rendah mengenai pemeriksaan IVA akan cenderung tidak menyadari bahaya kanker serviks dan pentingnya melakukan deteksi dini kanker serviks melalui pemeriksaan IVA. Pengetahuan yang rendah dapat menghambat seseorang umtuk melakukan pemeriksaan IVA.

\section{Keikutsertaan WUS dalam Melakukan Pemeriksaan Inspeksi Visual Asam Asetat}

Berdasarakan hasil penelitian didapatkan dari 53 responden yang melakukan pemeriksaan IVA sebanyak 30 orang $(56,6 \%)$, yang tidak melakukan pemeriksaan IVA sebanyak 23 orang $(43,4 \%)$. Analisis hubungan menunjukan bahwa statistik sikap berhubungan signifikan terhadap perilaku pemeriksaan IVA dengan $p=0,001$. Respon positif seseorang ditunjukkan dari sikapnya. Jika reaksi atau respon bersifat positif, maka perilaku cenderung positif dan jika respon negative, maka perilaku cenderung negatif juga. Jika seseorang mempunyai sikap positif terhadap pemeriksaan IVA, maka seseorang akan melakukan pemeriksaan IVA.

Hasil penelitian ini sejalan dengan penelitian sebelumnya yang dilakukan oleh (Dewi et al., 2020). Penelitian tersebut mengkaji tentang sikap wanita usia subur dalam melakukan deteksi dini kanker serviks melalui tes IVA di wilayah Kerja Puskemas Sawan I. Hasil penelitian menunjukkan bahwa sikap tersebut berhubungan secara signifikan dengan dukungan suami. Namun menurut Lestari et al., (2020) tidak ada hubungan yang signifikan antara dukungan suami dengan perilaku pemeriksaan IVA. Dengan demikian masih ada faktor lain yang mempengaruhi sikap dalam melakukan pemeriksaan IVA bila dibandingkan antara penelitian yang sudah dilakukan sebelumnya dengan penelitian yang dilakukan oleh peneliti. 


\section{Analisis Hubungan Tingkat Pengetahuan dengan Keikutsertaan WUS dalam Pemeriksaan IVA}

Hasil penelitian menunjukan ada hubungan yang signifikan antara pengetahuan dengan keikutsertaan WUS dalam melakukan pemeriksaan IVA $(\mathrm{p}=0,001)$. Hasil penelitian ini menunjukkan bahwa semakin tinggi pengetahuan WUS tentang kanker serviks akan meningkatkan keikutsertaan dalam melakukan pemeriksaan IVA. Dalam kondisi ini, seseorang yang memiliki pengetahuan memiliki perilaku dalam pencegahan sehingga akan melakukan deteksi lebih awal.

Hasil penelitian ini sejalan dengan penelitian yang dilakukan oleh (Jaya et al., 2020). Hasil penelitian menunjukkan cakupan pemeriksaan IVA dapat dihubungkan dengan pengetahuan. Oleh karena itu, diperlukan berbagai upaya untuk menyusun program yang tepat untuk meningkatkan pengetahuan tentang kanker serviks. Salah satu upaya yang dilakukan adalah dengan mengadakan pendidikan kesehatan. Penelitian lain yang dilakukan oleh Sukmawati et al., (2020) juga menunjukkan bahwa ada perbedaan tingkat pengetahuan sebelum dan sesudah dilakukan pendidikan kesehatan. Diharapkan tindak lanjut dari Puskesmas agar bekerjasama dengan kader untuk meningkatkan keikutsertaan pemeriksaan IVA.

Penelitian ini juga sejalan dengan penelitian yang dilakukan oleh Dewi et al., (2019) yang melakukan penelitian terhadap WUS yang melalukan pemeriksaan IVA. Penelitian ini membuktikan bahwa pengetahuan meningkatkan cakupan pemeriksaan IVA dalam lingkuh Puskesmas. Oleh karena itu, maka diperlukan berbagai upaya yang dapat dilakukan dan diberikan pada WUS. Hal ini penting untuk meningkatkan minat, motivasi dan kesediaan dalam melakukan pemeriksaan IVA. Selain itu, upaya-upaya preventif lain juga perlu dirancang untuk meningkatkan motivasi dan acuan bagi petugas kesehatan untuk memberikan edukasi tentang kanker serviks.

\section{SIMPULAN}

Pengetahuan memiliki korelasi dengan keikutsertaan WUS dalam melakukan deteksi dini kanker serviks dengan metode IVA. Dengan demikian ibu dengan pendidikan kategori baik lebih banyak melakukan pemeriksaan IVA.

\section{SARAN}

Peneliti berharap bahwa temuan ini dapat menjadi referensi dan menjadi data awal untuk melakukan penelitian lanjutan yang berhubungan antara tingkat pengetahuan terhadap keikutsertaan WUS dalam melakukan pemeriksaan IVA. Bagi peneliti selanjutnya diharapkan dapat menyusun berbagai model intervensi untuk meningkatkan pengetahuan dan keikutsertaan dalam tes IVA. Bagi keilmuan penelitian ini diharapkan dapat dijadikan sumber informasi dalam melakukan penelitian tentang WUS dalam melakukan pemeriksaan IVA

\section{DAFTAR PUSTAKA}

Adyani, K., \& Realita, F. (2020). Factors that Influence the Participation among Women in Inspection Visual Acetic Acid (IVA) Test. Jurnal Aisyah : Jurnal Ilmu Kesehatan,5(2),115-121. https://www.aisyah.journalpress.id/index.php/jika/article/view/5219/pdf

Dewi, N. K. P., Sumiasih, N. N., \& Somoyani, N. K. (2019). Hubungan antara Pengetahuan Wanita Usia Subur tentang Kanker Serviks dengan Keikutsertaan Pemeriksaan Inspeksi Visual Asam Asetat. Jurnal Ilmiah Kebidanan, 7(1). 
https://www.ejournal.poltekkes-denpasar.ac.id/index.php/JIK/article/view/918

Dewi, P. I. S., Sandy, P. W. S. J., \& Dewi, D. A. C. K. D. (2020). Sikap Wanita Usia Subur dalam Melakukan Deteksi Dini Kanker Serviks Melalui Dukungan Suami. Jurnal Keperawatan Silampari, 4(2017), 257-264. https://doi.org/https://doi.org/10.31539/jks.v4i1.1766 SIKAP

Dinas Kesehatan Provinsi Bali. (2019). Profil Kesehatan Provinsi Bali Tahun 2019. https://www.diskes.baliprov.go.id/profil-kesehatan-provinsi-bali/

Jaya, A., Supodo, T., \& Fatmawati. (2020). Faktor yang Berhubungan dengan Cakupan Pemeriksaan Inspeksi Visual Asam Asetat (IVA) di Kota Kendari. Jurnal Ilmiah Kebidanan, 6(2), 85-94. https://doi.org/https://doi.org/10.33023/jikeb.v6i2.513

Lestari, H., Kisid, K. M., \& Hardiani, S. (2020). Hubungan Pengetahuan dan Dukungan Suami dengan Perilaku Pemeriksaan Inspeksi Visual Asam Asetat (IVA) pada Wanita Usia Subur Sepulau Lombok Nusa Tenggara Barat Tahun 2020. PRIMA, 6(2), 61-68. https://doi.org/http://dx.doi.org/10.47506/jpri.v6i2.183

Nuryawati, L. S. (2020). Tingkat Pengetahuan tentang Kanker Serviks dengan Pemeriksaan IVA Test pada Wanita Usia Subur (WUS). Syntax Literate: Jurnal Ilmiah Indonesia, $5(12)$ 1636-1645. https://doi.org/http://dx.doi.org/10.36418/syntax-literate.v5i12.1842

Rahmi, L., \& Sinta, L. El. (2020). Faktor-Faktor yang Mempengaruhi Pemeriksaan Inspeksi Visual Asam Asetat (IVA). JIK, 4(2), 72-77. https://doi.org/10.33757/jik.v4i2.288.g123

Sukmawati, S., Mamuroh, L., \& Nurhakim, F. (2020). Pendidikan Kesehatan dan Pelaksanaan IVA Test pada Wanita Usia Subur. Media Karya Kesehatan, 3(1), 39-49. http://jurnal.unpad.ac.id/mkk/article/download/24916/12792

Winarni, W., \& Kanti, K. (2020). Keikutsertaan Deteksi Dini Kanker Leher Rahim Ditinjau dari Karakteristik Responden. GASTER, 18(1), 89-97. https://doi.org/10.30787/gaster.v18i1.532 